\title{
THE TRANSMISSION MECHANISM OF RUSSIAN CENTRAL BANK'S COUNTERCYCLICAL MONETARY POLICY SINCE 2011: EVIDENCE FROM THE INTEREST RATE PASS-THROUGH
}

\author{
Chu V. Nguyen \\ Marilyn Davies College of Business, University of Houston Downtown, United States \\ Phan Dinh Khoi \\ College of Economics, Can Tho University, Vietnam \\ Marvin J. Williams \\ Marilyn Davies College of Business, University of Houston Downtown, United States
}

\begin{abstract}
This study is an investigation of the nature of the Russian interest rate pass-through from February 2011 to November 11, 2016. The empirical results reveal a relatively low short-run interest pass-through of 0.662937 and an incomplete long-run interest rate pass-through of 0.826353 . The bounds test results indicate no long-term relationship between countercyclical monetary policy and market rates. These empirical findings suggest that the Russian Central Bank has not been very effective in formulating and implementing its countercyclical monetary policy. In light of the formidable political and economic challenges faced by the Russian Federation over this sample period, the results are hardly surprising.
\end{abstract}

Keywords: Monetary policy, Commercial banks, Lending rate, Interest rate pass-through, Central Bank policy related rate, Russian Federation.

DOI: http://dx.doi.org/10.15549/jeecar.v4i2.165

\section{INTRODUCTION}

The international economic landscape has increasingly been shaped by political and social turmoil in the past decade, which in turn has caused the Russian banking sector to become more internationalized during this period. A critical facilitator of investment and economic growth is financial intermediation (Schumpeter, 1912; Patrick, 1966; McKinnon, 1973). Commercial banks are an integral part of the monetary policy transmission mechanism. This is due to the use of the interest rate passthrough by commercial banks to change lending rates in the economy, which in turn transmit countercyclical monetary policy measures to consumption and investment activities. The macroeconomic policy target variables of unemployment, inflation and real gross domestic product (GDP) are changed by any changes in these two macroeconomic variables.

Often regarded as a serious obstacle to the smooth transmission of monetary policy impulses, is the stickiness of bank lending rates 
with respect to money market rates. In addition, Illes and Lombardi (2013) articulated that the transmission of policy rates to lending (and deposit) rates - the interest rate pass-through is far from mechanical and is affected by multiple factors. To further emphasize this point, financial intermediaries may require higher compensation for risk in response to slowing economic activity. A reduction in the policy related rate would only be partially passed on to firms or households in this case. On the other hand, low perceived risk can magnify the impact of the pass-through and lead to an overheated economy.

In regards to the Russian economy, the International Monetary Fund (IMF) (2016-a) reported that a sharp decline in oil prices and reduced access to international capital markets due to sanctions, contributed to a $3.7 \%$ contraction in the Russian Gross National Product (GDP) in 2015. Moreover, the Russian currency (ruble) was subjected to severe pressure at end-2014 in light of concerns about external debt redemptions. This pressure resulted in the Central Bank of Russia Federation (CBR) to install anti-crisis measures in Late 2014-15 to stabilize the financial system. In order to lessen foreign exchange reserve losses, the CBR floated the exchange rate and hiked its policy related rate by 650 basis points to 17.00 $\%$. With the depreciation of the Russian ruble and Russia's imposition of a food import ban in response to sanctions, inflation accelerated sharply, peaking at $17.0 \%$ in March 2015 before declining to $7.5 \%$ by April 2016. In response to this inflationary effect, the CBR cut the policy rate in stages, most recently to $10.5 \%$ in June 2016.

Gustavo et al. (2016) posited that a lack of adequate supervision in the banking sector, the relative ease in obtaining licenses to operate banks, and few lending opportunities available to lending institutions after the collapse of the U.S.S.R., led to a sharp increase in the number of commercial banks in the early 1990s, rising to nearly 2,700 banks by 1995 . However, the regulation of the Russian banks became stricter after the appointment of Elvira Nabiullina as the head of the CBR in 2013, resulting in fewer bank licenses and more resolution processes put in place at many Russian commercial banks.

Gustavo et al. (2016) also pointed out that the Russian banking system is currently comprised of more than 600 banks with the three largest banks (Sberbank, VTB and Gazprombank) accounting for $60 \%$ of the nation's total assets and $71 \%$ of the nation's total loans as of 2015. The concentration of these three largest banks has become stronger over a relatively short period of time, as these three banks accounted for only $53 \%$ of the nation's total assets and $64 \%$ of the nation's total loans as recently as 2012.

Gustavo et al. (2016) concluded that the sharp decline in oil prices, combined with Western sanctions and Russian counter-sanctions following the Russia-Ukraine conflict, had a negative impact on the Russian economy and banking sector in recent years. Since 2014, the industry has reflected a weaker performance with profit indicators narrowing and nonperforming loans (NPLs) increasing. To prevent a downfall in the country's financial system, the CBR introduced forbearance measures to offset financial market stress on banks' balance sheets and implemented a number of changes in banking regulation. At this time, many banks (primarily major state-owned) were heavily capitalized through the Deposit Insurance Agency. Despite the CBR announcing a number of new regulatory changes ranging from stringent controls on off-shore holdings to stronger stress tests, the Russian banking sector remains exposed to a number of potential damaging risks.

According to the IMF (2016-b), banking represents the most significant sector of the Russian financial system, although the role of the nonbank sector has been steadily growing. Bank assets amounted to 103 \% of the Russian GDP at end-2015. The nonbank sectors of the pension funds, insurance, and mutual funds had assets at this same time of $3.6 \%, 2.0 \%$ and $3.3 \%$ of GDP, respectively. Moreover, Russia has the lowest bank credit-to-GDP ratio among a group of comparable countries composed of Brazil, India, China, and South Africa. Among these comparable countries, Russia tends to show slightly lower depth in its financial markets. However, Russia shows much greater financial development, reflecting higher access and efficiency than these comparable countries.

As further shown by the IMF (2016-b), the Russian banking system is relatively concentrated at the top but is otherwise fragmented. In its relatively short period of time, the banking system has experienced a strong concentration phase going from 1,311 banks in 
2001 to less than half that number by the end of 2015, with the largest 20 banks accounting for three quarters of the system's total assets. Government-related banks, dominated by Sberbank and VTB Group, accounted for $60 \%$ of the system assets at the end of 2015. The top ten private universal banks hold $16 \%$ of the system assets, foreign-owned banks owning $13 \%$, and $11 \%$ is owned by specialized and small banks. In addition to assets ownership, lending in the Russian banking system is also highly concentrated as the top ten banks by assets accounted for about $70 \%$ of total lending as of January 2016. Of particular significance, Sberbank and VTB Group, two (2) of the three (3) largest banks in Russian, together accounted for a similar share of the total lending as the remaining $700+$ banks combined. It is worthy to note that many of the small banks in Russia operate in mono-industrial-cities and are often systemically important for their respective regions.

As also pointed out by the IMF (2016-a), the loan portfolio quality and profitability of Russian banks have deteriorated. NPLs have increased with household overdue loans reaching $8.4 \%$ of total loans by February 2016 , as compared to $6.5 \%$ of total loans for the corporate sector. Overall NPLs were stable in MayDecember 2015 due to the loan rescheduling and regulatory forbearance introduced by the CBR. Furthermore, bank profitability has dropped markedly - with the return on assets reaching $0.3 \%$ at the end of 2015-to levels similar to those observed during the great financial crisis. The reasoning for these developments are several. Revenue has been adversely impacted due to net interest margins being reduced, reflecting slower asset growth and higher policy rates. A corollary of this is that net fees and commissions likewise have decreased in correspondence with the reduction in the net interest margins. Moreover, expenditures such as non-interest expenses declined at a lower rate than net interest income, while at the same time provisions for NPLs have risen sharply owing to the deterioration in loan portfolios.

A possible benefit of the CBR being transformed into a "mega regulator" as noted by the IMF (2016-a), financial supervision in the Russian banking system has been enhanced. Since 2013, the CBR has overseen banks, securities markets, financial market infrastructure, private pension funds, insurance, and micro-finance institutions. Consistent regulation and supervision for nearly the entire financial system is a result of this expansive reform. In addition, in recent years the CBR has also made far-reaching changes to the legal and supervisory landscape. Legislative obstacles to cooperation and collaboration based on domestic and cross border supervisory information exchange have been eliminated. A direct result of all of these measures and actions is the enhancement of the scope and application of consolidated supervision. The CBR even now has the power to impose standards for the risk management of banks and banking groups.

Finally, the IMF (2016-a) reported that the CBR is developing and enhancing its risk-based approach to supervision. This has been achieved by the CBR sharpening its risk focus by differentiating its approach to supervision. The CBR has recently issued regulations that focus on the quality of risk management and governance within firms which will introduce, for example, scrutiny of firms' risk appetite.

In view of the information presented above, learning of the nature of the Russian interest rate pass-through is of particular interest. The objective of this study is to investigate how Russian commercial banks passed changes in their cost of funds to their customers through the short-run and long-run interest rate passthrough processes since February 2011. These changes are due to countercyclical monetary policy, as reflected in changes in the Central Bank policy related rate. The remainder of the paper is structured as follows: Section 2 briefly reviews the literature. Section 3 describes the econometric methodology, specifies an empirical model for the investigation and the estimation method to calculate the passthrough. Section 4 describes the data set. Section 5 presents estimation results. Section 6 briefly discusses the empirical findings. Finally, Section 7 summarizes and concludes the paper.

\section{REVIEW OF LITERATURE}

Many approaches and methodologies have been used to study interest rate setting behaviors of lending institutions around the globe. Espinosa-Vega and Rebucci (2003) applied a standard error correction model to consider whether interest rate pass-through in Chile's experience was atypical compared to ten other countries, including the United States. The authors found that the adjustment in the 
Chilean banking sector was incomplete - like in other countries - but generally faster than those in the rest of their sample. Also, Espinosa-Vega and Rebucci (2003) reported that the adjustment process was affected by institutional changes in the exchange rate regime and Chile's monetary policy targeting. Nguyen (2017) investigated the nature of the Brazilian interest rate pass-through from January 1997 through June 2016. The empirical results suggest (1) lending rate stickiness in the short run, (2) overshooting in the long run and (3) a long lag for monetary policy impact.

Hofmann and Mizen (2004) used seventeen years of monthly data for rates on thirteen deposit and mortgage products offered by UK financial institutions to empirically investigate the potential non- linearity in adjustment of retail rates to base rates due to menu costs. They reported that the speed of adjustment responded nonlinearly to the expected size of the gap between the base rate and retail rate in the near future. In other words, the perceived "aggressiveness" in base rate management was a significant factor explaining the speed of passthrough effects.

Sørensen and Werner (2006) performed Euroarea cross-country comparisons and reported empirical evidence of high-degree heterogeneity in pass-through of base rates to bank interest rates. Among other cyclical and structural factors, Sørensen and Werner (2006) found different degrees of competition in the national banking sector to be the most significant determinants of pass-through speed.

Tonooka and Koyama (2003) searched for but found no relationship between interest rates on loans and market concentration in the Brazilian banking sector. Alencar (2003) estimated the speed of pass-through effects from changes in benchmark interest rates and compared them to those observed in retail banking. The revelation that the time lag for monthly-average retail rates to fully adjust to changes in the opportunity cost of money is less than 12 months, was pointed out as evidence of a significant degree of competition, driving banks to operate efficiently.

Bernanke and Blinder (1992) investigated the response of credit aggregates to monetary policy shocks. Borio and Fritz (1995) and Cottarelli and Kourelis (1994) focused more specifically on the pass-through of policy rates to lending rates, which is also the focus of this

investigation. Studies on the heterogeneity in the pass-through at the individual bank level are limited to a few country studies (Weth, 2002; Gambacorta, 2008). The majority of the empirical literature has resorted to cointegrated time series models developed by Engle and Granger (1987) to account for co-movements of policy and lending rates. European Central Bank (2013) focuses on major Euro-area countries, reporting evidence of heterogeneity between core and peripheral countries. Additionally, Coelho, De Mello, and Garcia (2010) found that the Brazilian pass-through is higher for larger banks using a sample from June 2000 to December 2006.

Moreover, the monetary policy regime can affect adjustments and volatility of retail rates. For example, one would expect nominal prices to adjust faster or the pass-through to be larger when inflation is higher (Mojon, 2000). The important factors of the country's financial structure are bank competition, development of financial markets, and banking system ownership. If financial markets are well developed, financially solid businesses tend to opt for alternative sources of finance when retail rates rise, increasing overall risks of banks' loan portfolios. In that case, banks increase lending rates to compensate for higher risks instead of rationing credit (Sander and Kleimeier, 2004).

Dhal and Ansari (2013) reported that (i) the Indian commercial banks' loan pricing decisions depend upon alternative measures of loan interest rate and spreads and interest rate passthrough; (ii) the pass-through from the policy rate to loan interest rates could be limited when commercial banks consider several factors, including the policy rate for their loan pricing decisions; (iii) the problem of pass-through evident from differential impacts of interbank money market rate and the repo rate, could relate to the alignment between liquidity and interest rate channels of transmission mechanism; (iv) higher capital charge can induce risk aversion and positively affect loan interest rate; and (v) bank size variable, which is often considered for gauging economies of scale effect, does not hold for the Indian context.

\section{METHODOLOGY AND MODEL SPECIFICATION}

\section{Structural Break and its implication}

It is expected that long time series data will experience structural breaks. Model 
misspecification may result if there is a failure to account for structural breaks. In monetary economics, when the structure of interest rate breaks occur in an economy, usually as result of economic shocks, the Central Bank often reacts by implementing countercyclical monetary policy measures. Therefore in reality, there is an interaction between the structural break and policy rate.

To account for possible structural breaks, this $S P_{t}=\mu+\theta D U+\alpha t+\gamma D T+\delta D\left(T_{b}\right)+\beta S P_{t-1}+\sum_{i=1}^{k} \psi_{i} \Delta S P_{t-i}+v_{t}$

where $\quad D U=1\left(t>T_{b}\right) \quad$ is a post-break constant dummy variable; $t$ is a linear time trend; $D T=1\left(t>T_{b}\right)$ is a post-break slope dummy variable; $D\left(T_{b}\right)=1\left(t=T_{b}+1\right)$ is the break dummy variable; and $v_{t}$ are white-noise error terms. The null hypothesis of a unit root is stated as $\beta=1$. The break date, $T_{b}$, is selected based on the minimum t-statistic for testing $\beta=1$ (Perron, 1997).

The common methodology to account for a structural break is to introduce a dummy independent variable $d_{t}$ with the value of 1 from the structural break date onward and 0 elsewhere. In the banking sector, a structural break is usually caused by a shock which precipitates countercyclical monetary policy action by the Central Bank which results in an interaction between the structural break dummy and countercyclical monetary policy measure. Let $z_{t}$ be an independent variable measuring the effect of the interaction between the structural break and policy rate.

$$
i_{t}=\mu+\sum_{j=1}^{n} \beta_{j} i_{t-j}+\sum_{k=0}^{m} \delta_{k} r_{t-k}+\sum_{l=0}^{s} \rho_{l} z_{t-l}+\varepsilon_{t}
$$

where $i_{t}$ is the lending interest rate and $r_{t}$ is the Central Bank policy related rate at time $t$. As defined above, $Z_{t}$ is an independent variable measuring the effect of the interaction between the structural break and policy rate. $\delta_{0}+\rho_{0}$ is the short-run effect - within the month after the Central Bank changes the policy related rate. It is a priori expectation that $0<\delta_{0}+\rho_{0} \leq 1 . \delta_{0}+\rho_{0}$ $<1$ indicates sluggish adjustment, also known as lending rate stickiness. $\delta_{0}+\rho_{0}=1$ represents a complete pass-through in the short run. analysis defined the spread, denoted by $S P_{t}$, as the difference between the two time series. To search endogenously for the possibility of any structural break in the relationship between the two time series, this study utilized Perron's (1997) endogenous unit root test function with the intercept, slope, and the trend dummy to test the hypothesis that the spread has a unit root.

Theoretically, the two regressors $d_{t}$ and $z_{t}$ are highly correlated, and only $z_{t}$ is included in the model to account for both the structural break and countercyclical monetary policy precipitated by the shock causing the structural break, and to avoid possible single matrix in the estimation process.

\section{Model Specification}

To investigate the reactions to or how the Russian commercial banks responded to changes in countercyclical monetary policy measures by the Russian Central Bank reflected in changes in the policy related rates, i.e., the Russian interest pass-through, this study follows Wickens and Breusch (1988) and Pereira and Maia-Filho (2013) to specify and estimate an Autoregressive Distributed Lag [ARDL(n,m,s)] model hypothesizing the relationship between the endogenous variable $i_{t}$, the independent variables $r_{t}$ and $z_{t}$.
Theoretically, the ARDL method proposed by Pesaran et al. (1997) has been a valuable tool for testing for the presence of long-run relationships between economic time-series. The advantage of the ARDL model is its ability to estimate both the long-term and short-term model parameters without requiring a pretesting to determine the order of the cointegration of the variables, thus avoiding the problems posed by non-stationary time series. This pre-testing is particularly problematic in the unit-root cointegration literature where the power of the unit-root tests is typically very low, 
and there is a switch in the distribution function of the test statistics as one or more roots of the right hand side variables process approach unity. Furthermore, the ARDL procedure is robust to small samples, allowing different optimal lags of variables.

However, Pereira and Maia-Filho (2013) argued that the bounds test is based on the assumption that variables are either $\mathrm{I}(0)$ or $\mathrm{I}(1)$. Therefore, it is prudent to determine the stationarity of the time series data. The most common testing procedures to test for stationarity of time series data are Kwiatkowski-Phillips-Schmidt-Shin and Phillips - Perron.

As to the empirical estimation, Enders (2015) suggested that the process to estimate the coefficients for equation (1) is to utilize the Akaike information criterion to select the largest values of $n, m$ and s, deemed feasible; CUSUM and the CUSUM of Squares tests are used to test for model stability. Breusch-Godfrey Serial Correlation Lagrange (LM) multiplier Test is then used as diagnostics to test the hypotheses that the residuals $\left\{\varepsilon_{t}\right\}$ are white noises.

As articulated by Pereira and Maia-Filho (2013), given the estimation results for equation (2), the long- run effect is calculated

$$
\Delta i_{t}=\varphi+\sum_{j=1}^{n} \eta_{j} \Delta i_{t-j}+\sum_{k=0}^{m} \pi_{k} \Delta r_{t-k}+\sum_{l=0}^{s} \omega_{l} \Delta z_{t-l}+\lambda_{1} i_{t-1}+\lambda_{2} r_{t-1}+\lambda_{3} z_{t-1}+\varepsilon_{t}
$$

where $\Delta$ is difference operator and the null hypothesis of "non-existing of the long-run relationship" is stated as $\lambda_{1}=\lambda_{2}=\lambda_{3}=0$. The relevant F-statistics for the joint significance of the $\lambda^{\prime} s$ are calculated and compared with the critical values tabulated by Pesaran, Shin, and Smith (2001). If the estimated F-statistic is greater than the upper bound critical value, the variables are cointegrated. If it is below the lower bound, the null hypothesis cannot be rejected, i.e., there is no support evidence for long-run relationship between countercyclical monetary policy and market rates.

$$
\Phi=\frac{\sum_{k=0}^{m} \delta_{k}+\sum_{l=0}^{s} \rho_{l}}{1-\sum_{j=1}^{n} \beta_{j}}
$$

As articulated by Berstein and Fuentes (2003), $\Phi$ should be positive and close to 1 . $\Phi=1$ implies a complete pass-through in the longrun, which can be considered evidence of significant competition in the banking system. If $\Phi<1$ or $\Phi>1$, it implies either stickiness (less than perfect pass-through) or overshooting, respectively, of retail rates with respect to changes in the policy rate. Explanatory factors include monetary policy regime and the country's financial structure (Sørensen and Werner, 2006).

It is therefore important to study the long-run relationship between countercyclical monetary policy and market rates. To this end this investigation follows Pereira and Maia-Filho (2013) to use the bounds testing approach (Pesaran, Shin, and Smith, 2001) for the following error correction representation of the Autoregressive Distributed Lag model:

\section{DATA}

To empirically discern the aforementioned issues, this study uses the Russian lending rates $i_{t}$ and Central Bank policy related rate $r_{t}$ from February 2011 through November 2016 (when data is available) to estimate the autoregressive distributed lag model (2). Figure 1 illustrates the Russian lending rate, Central Bank policy related rate and their spread. All time series data are collected from the International Financial Statistics, published by the International Monetary Fund. 


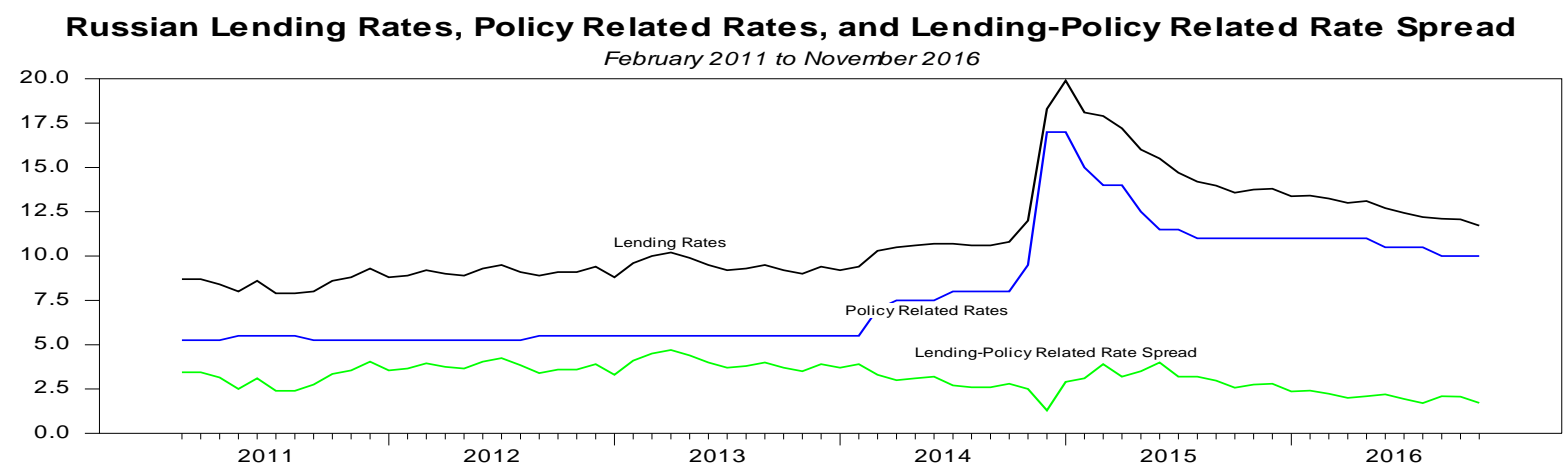

Figure 1: Russian lending rate in the credit markets, Central Bank policy related rate and their spread.

\section{EMPIRICAL RESULTS}

The empirical results for this investigation are reported as follow.

\section{The Degree of Cointegration}

The bounds test is based on the assumption that variables are either $\mathrm{I}(0)$ or $\mathrm{I}(1)$. The most common testing procedures to test for stationarity of time series data are Kwiatkowski-Phillips-Schmidt-Shin and Phillips-Perron. The results of Kwiatkowski-
Phillips-Schmidt-Shin and Phillips-Perron tests of the Russian lending rates $i_{t}$ and Central Bank policy related rate $r_{t}$ are summarized in Exhibit 1. The unit root tests reveal lending rate $i_{t}$ is an $\mathrm{I}(1)$ and Central Bank policy related rate $r_{t}$ is also an $\mathrm{I}(1)$. Pereira and Maia-Filho (2013) argued that it is appropriate to use the bounds test to check for cointegration.

Exhibit 1: PP and KPSS Test Results, Russian Monthly Data , 2011:02 - 2016:11

\begin{tabular}{lcccc} 
& \multicolumn{2}{c}{ Phillips-Perron } & \multicolumn{2}{c}{ Kwiatkowski-Phillips-Schmidt-Shin } \\
\cline { 2 - 5 } Series & Level & Differencing & Level & Differencing \\
\hline$i_{t}$ & $-1.626791^{\mathrm{n}}$ & $-5.834076^{\mathrm{y}}$ & $0.730242^{\mathrm{n}}$ & $0.081754^{\mathrm{y}}$ \\
$r_{t}$ & $-1.488662^{\mathrm{n}}$ & $-6.338820^{\mathrm{y}}$ & $0.806392^{\mathrm{n}}$ & $0.071530^{\mathrm{y}}$ \\
\hline
\end{tabular}

Note: " ${ }^{\prime \prime}$ and $"{ }^{\prime \prime}$ indicate whether the series is non- stationary and stationary 5.0\%level

Structural Break

The estimation results for Perron's (1997) endogenous unit root test function with the intercept, slope, and the trend dummy are summarized in Exhibit 2.

Exhibit 2: Perron's Endogenous Unit Root Test, Russian Data - 2011:02- 2016:11

$$
\begin{gathered}
S P_{t}=1.27162+2.41788 D U-0.00268-0.04392 D T-1.41788 D\left(T_{b}\right)+0.64979 S P_{t-1}+v_{t} \\
\left(4.24687^{*}\right) \quad\left(3.35192^{*}\right)(-0.64056) \quad\left(-3.34903^{*}\right) \quad\left(-4.53301^{*}\right) \quad\left(8.16621^{*}\right)
\end{gathered}
$$

Number of augmented lags: $k=0 \quad \begin{gathered}\text { Break } \\ 2011\end{gathered}$ Date: November $t(\alpha=1)=-4.40117^{* * *}$

Notes: Critical values for t-statistics in parentheses. Critical values based on $n=100$ sample for the break date (Perron, 1997). "“" and " ""*" indicate significances at 1.0\% and 10.0\% levels. 
The estimation results reveal that the postbreak intercept dummy variable, $D U$, is positive and the post-break slope dummy variable, $D T$, is negative and they are both significant at $1 \% \mathrm{t}$, while the break dummy, $D\left(T_{b}\right)$ is negative and is significant at any conventional level. The time trend, $t$, is negative and is insignificant at the $10 \%$ level. These results suggest that the spread follows a stationary trendless process. Moreover, strength of the test statistic $t(\alpha=1)=-4.40117$ confirms the structural break in November 2014. Since the significant level of the t-statistic is only at $10 \%$, the Chow test was calculated and the result supported the structural break date. This endogenously determined structural break may be attributable to the impact of the sharp decline in oil prices, combined with Western sanctions and Russian counter-sanctions following the RussianUkraine conflict, which had negative impact on the Russian economy and banking sector (Gustavo et al., 2016).

\section{ARDL Model}

As discussed in the methodology section and based on the Akaike information criterion, the estimation process indicates that the optimal values are $n=1, m=5$, and $\mathrm{s}=5$ as the reported values for AIC in Exhibit 4 suggests. The ARDL $(1,5,5)$ model has the lowest AIC value, and therefore it will be used for this investigation. The estimation results and diagnostic statistics for the autoregressive model, $\operatorname{ARDL}(1,5,5)$ are summarized in the following Exhibits 3, 4 and Figure 1.

Exhibit 3: Estimation Results for ARDL $(1,5,5)$ Model and Bounds Test, 2011:02 - 2016:11

\begin{tabular}{|c|c|c|c|c|c|}
\hline \multicolumn{3}{|c|}{$\operatorname{ARDL}(1,5,5):{ }^{i_{t}}$ is a dependent variable } & \multicolumn{3}{|c|}{ ARDL Bounds Test: ${ }^{\Delta i_{t}}$ is a dependent variable } \\
\hline Variable & Coefficient & t-statistic & Variable & Coefficient & t-statistic \\
\hline$i_{-1}$ & $0.783480^{*}$ & 11.37364 & $\Delta r_{0}$ & $0.646628^{*}$ & 4.840793 \\
\hline$r_{0}$ & $0.646628^{*}$ & 11.94377 & $\Delta r_{-1}$ & $0.286971^{* *}$ & -2.176663 \\
\hline$r_{-1}$ & $-0.711696^{*}$ & -6.477271 & $\Delta r_{-2}$ & -0.033600 & -0.239459 \\
\hline$r_{-2}$ & $0.253370^{*}$ & 3.221871 & $\Delta r_{-3}$ & -0.092236 & -0.692948 \\
\hline$r_{-3}$ & -0.058636 & 0.960593 & $\Delta r_{-4}$ & $-0.300852^{*}$ & -3.127762 \\
\hline$r_{-4}$ & $-0.208616^{*}$ & -4.101154 & $\Delta z_{0}$ & $0.016309^{*}$ & 0.390841 \\
\hline$r_{-5}$ & $0.300852^{*}$ & 6.701899 & $\Delta z_{-1}$ & $0.192186^{* * *}$ & 1.945633 \\
\hline$z_{0}$ & 0.016309 & 1.155476 & $\Delta z_{-2}$ & $0.263824^{* *}$ & 2.357921 \\
\hline$Z_{-1}$ & $0.132897^{*}$ & 3.837796 & $\Delta z_{-3}$ & -0.167952 & -1.495993 \\
\hline$Z_{-2}$ & 0.071638 & 0.835314 & $\Delta z_{-4}$ & $0.327542^{*}$ & 3.184402 \\
\hline$Z_{-3}$ & $-0.431776^{*}$ & -4.046861 & $i_{-1}$ & $-0.216520^{*}$ & 3.822255 \\
\hline$Z_{-4}$ & $0.495494^{*}$ & 6.753151 & $r_{-1}$ & $0.221903^{* *}$ & 2.306141 \\
\hline$Z_{-5}$ & $-0.327542^{*}$ & -6.693295 & $Z_{-1}$ & -0.042981 & 0.317290 \\
\hline constant & $0.796932^{*}$ & 2.423279 & Constant & $0.796932^{* *}$ & 2.043015 \\
\hline $\begin{array}{l}R^{2}=0.992079 \\
F \text {-value }=49\end{array}$ & $\begin{array}{l}\bar{R}^{2}=0 . \\
\text { and AIC }\end{array}$ & $\begin{array}{l}0059 \\
0.511628\end{array}$ & $\begin{array}{l}R^{2}=0.92603 \\
F \text {-value }=49\end{array}$ & $\begin{array}{r}\bar{R}^{2}=0.90 \\
\text { Bounds Test }\end{array}$ & $3.234231, \mathrm{k}=2$ \\
\hline
\end{tabular}

Note: “*”, “**” and “***”indicate $1 \% t, 5 \%$ and $10 \%$ significance levels, respectively.

Critical values for bounds tests at $10 \% \mathrm{t}: \mathrm{I}(0)=2.63, \mathrm{I}(1)=3.35$;

$5 \% \mathrm{t}: \mathrm{I}(0)=3.10, \mathrm{I}(1)=3.87 ; 1 \% \mathrm{t}: \mathrm{I}(0)=4.13, \mathrm{I}(1)=5.00$. 
The left panel of Exhibit 4 reports the diagnostic tests testing for the correlation among the independent variables, and the possibility for the variance of the error term to depend on regressors included in the estimated the model. The right panel of Exhibit 4 reveals the AIC-values of the five best estimated models.

Exhibit 4: Diagnostic Tests and Five Best Models According to AIC Criteria; 2011:02-2016:11

\begin{tabular}{|c|c|c|}
\hline Diagnostic Tests & \multicolumn{2}{|c|}{ Model Selection Criteria } \\
\hline & Five Best Models & $A I C$ \\
\hline $\begin{array}{l}\text { Breusch-Godfrey Serial Correlation LM Test: } \\
\qquad \begin{array}{l}H_{0} \text { : There is no serial correlation in the residuals. } \\
\mathrm{F}_{(2,49)}=0.633181, \quad \text { p-value }=0.5352\end{array}\end{array}$ & $\begin{array}{l}\operatorname{ARDL}(1,5,5) \\
\operatorname{ARDL}(1,6,5)\end{array}$ & $\begin{array}{l}0.269 \\
0.300\end{array}$ \\
\hline $\begin{array}{l}\text { Breusch-Pagan-Godfrey Heteroskedasticity Test: } \\
H_{0} \text { : The residual's variance is constant. } \\
\qquad \mathrm{F}_{(13.51)}=0.755344, \quad \text { p-value }=0.7010\end{array}$ & $\begin{array}{l}\operatorname{ARDL}(1,5,6) \\
\operatorname{ARDL}(2,5,5)\end{array}$ & $\begin{array}{l}0.304 \\
0.304\end{array}$ \\
\hline
\end{tabular}

Note: Data is from calculations by author.

Figure 2 illustrates the graphs of the CUSUM and the CUSUM of Squares Tests over the sample period.
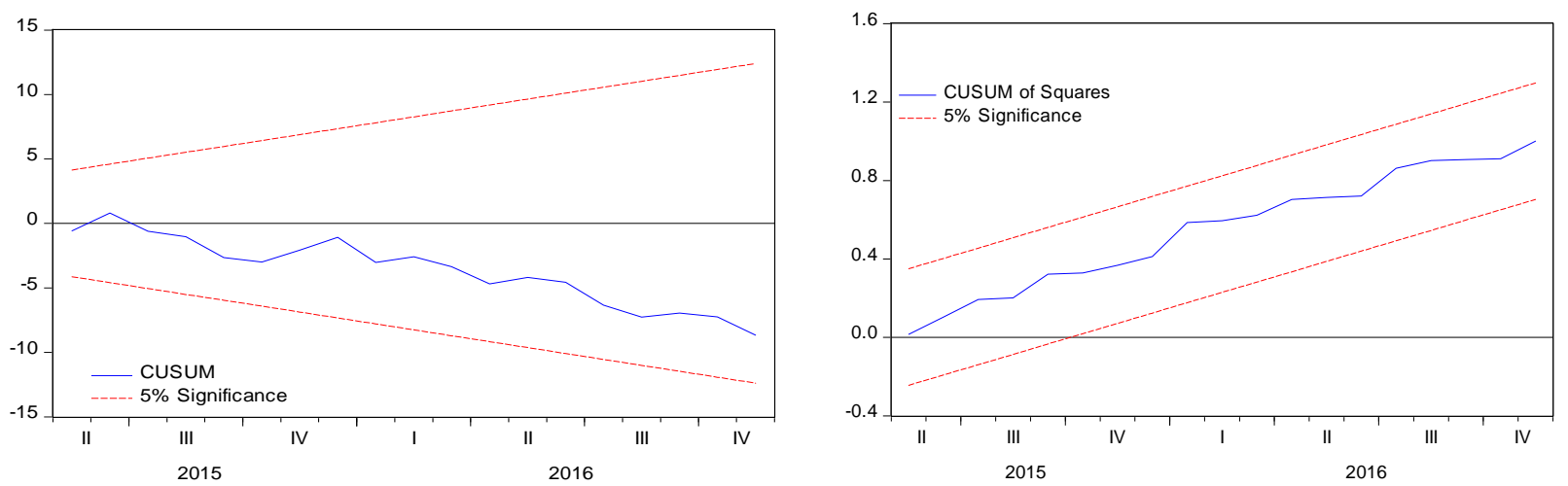

Figure 2: Graphs of CUSUM and CUSUM of Squares tests to test for stability of model's estimated parameters.

An analysis of the overall estimation results indicates that there exists no serial correlation and that the model exhibits strong predictive power, as evidenced by the strengths of the Breusch-Godfrey Serial Correlation Lagrange Multiplier Test $F(2,49)=0.633181$ with the $\mathrm{p}$ value being 0.5352, and the Breusch-PaganGodfrey Heteroskedasticity Test $\mathrm{F}_{(13,51)}=$ 0.755344 , which fail to reject the null hypothesis that there is no serial correlation in the residuals. As Figure 1 illustrates, the CUSUM Test and CUSUM of Squares Test fell well within the band of $5 \%$ level of significance over the sample period. These empirical findings indicate the stabilities of the estimated parameters of the model over the sample period. Overall the diagnostic analysis indicates that the estimated $\operatorname{ARDL}(1,5,5)$ model is very reliable.

As reported in Exhibit 3, the estimated sum of $\delta_{0}+\rho_{0} \quad$ is $\quad 0.662937$ $(0.646628+0.016309=0.662937)$. Also, using the equation (3), the following calculation indicates that the estimated long-run interest rate pass-through rate in the Russian banking

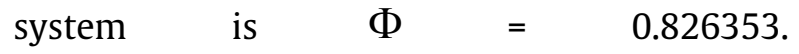




$$
\Phi=\frac{\sum_{k=0}^{m} \delta_{k}+\sum_{l=0}^{s} \rho_{l}}{1-\sum_{j=1}^{n} \beta_{j}}=\frac{0.221902-0.04298}{1-0.78348}=\frac{0.178922}{0.21652}=0.826353
$$

Finally, to test the null hypothesis of "nonexistence of the long-run relationship$H_{0}: \lambda_{1}=\lambda_{2}=\lambda_{3}=0$ ", the calculated value of the relevant $F$-statistic being 3.234231 for the joint significance of the hypothesis is compared to the critical values of the lower and upper bounds at $5 \%$ levels of significance. Comparing the value of the F-statistic of 3.234231 to the critical value of the lower bound $\mathrm{I}(0)=3.10$ and the upper bound $\mathrm{I}(1)=3.87$ indicates that testing result of the null hypothesis of "nonexistence of the long-run relationship" in the Russian banking sector is inconclusive, suggesting that there is no long term relationship between the Central Bank policy related rate and the lending rate in the Russian commercial banks' lending markets.

\section{DISCUSSIONS OF THE EMPIRICAL RESULTS}

he endogenous search process for breaks in the Russian interest rate structure using Perron's (1997) endogenous unit root test function with the intercept, slope, and the trend dummy found that the relationship between the Central Bank policy related rate and the commercial bank's lending rate experienced a break in November 2014 which is attributable to the impact of the sharp decline in oil prices, combined with Western sanctions and Russian counter-sanctions following the RussianUkraine conflict which had negative impact on the Russian economy and banking sector.

To account for the structural break, this investigation introduced a dummy variable and assigned the value of 1 from November 2014 onward and 0 elsewhere over the sample period. Econometrically, this introduction of the dummy variable precipitated the generation of the interaction term between the dummy variable and the Central Bank policy related rate. Exploratory analysis suggested that the estimated coefficient of the dummy variable is statistically insignificant, therefore, it is excluded in the modelling process. An analysis of the overall estimation results indicates that there exists no serial correlation and that the model exhibits strong predictive power and also confirms that the estimated residuals are white noise.

The estimation results of the Autoregressive Distributed Lag, ARDL (1, 5, 5) model, represented by equation (2), reveal that the Russian short-run rates of pass-through, $\delta_{0}+\rho_{0}$ $=0.662937$, is relatively high as compared to empirical values reported in the literature for the emerging and advanced economies (Alencar, 2011; Pereira and Maia-Filho, 2013; Nguyen, 2017; Wickens and Breusch, 1988).

Based on the Akaike information criterion, the longest lag retained by the estimation process for the commercial lending rate is $1\left(i_{-1}\right)$ and for the Central Bank policy related rate is $5\left(r_{-5}\right)$. These findings suggest that the Russian commercial banks considered their lending rate only one month back in determining their current lending rate; while these lending institutions took up five months to respond to the monetary policies completely. The calculated long-run pass-through rate in the Russian banking industry is $\Phi=0.826353$ which is fairly low, indicating that the Russian Long-term interest rate pass-through is incomplete or sticky, suggesting the ineffectiveness of this policy.

Finally, one way to measure the credibility of the Central Bank is the existence of the long-run relationship between its countercyclical monetary policy, as reflected in changes in the Central Bank policy related rate, and the commercial banks' lending rate in the lending markets. In this investigation, this issue is addressed by testing the above stated null hypothesis $H_{0}: \lambda_{1}=\lambda_{2}=\lambda_{3}=0$. The testing procedure indicated that the result is inconclusive, suggesting no long-run relationship between the countercyclical monetary policy and the commercial banks' lending rate in the lending markets.

\section{CONCLUDING REMARKS}

Financial intermediation is a critical facilitator of investment and economic growth. Due to the use of the interest rate pass-through by commercial banks to change lending rates in the 
economy, which in turn transmit countercyclical monetary policy measures to consumption and investment activities, commercial banks are an integral part of the monetary policy transmission mechanism. The macroeconomic policy target variables of unemployment, inflation and real gross domestic product (GDP) are changed by any changes in these two macroeconomic variables.

The Russian currency (ruble) was subjected to severe pressure at end-2014 in light of concerns about external debt redemptions. This pressure resulted in the Central Bank of Russia Federation (CBR) to install anti-crisis measures in late 2014-15 to stabilize the financial system. In order to lessen foreign exchange reserve losses, the CBR floated the exchange rate and hiked its policy related rate by 650 basis points to 17.00 $\%$. Because of the depreciation of the Russian ruble and Russia's imposition of a food import ban in response to sanctions, inflation accelerated sharply, peaking at $17.0 \%$ in March 2015 before declining to $7.5 \%$ by April 2016. In response to these inflationary effects, the CBR cut the policy rate in stages, most recently to $10.5 \%$ in June 2016.

The information presented above motivated the investigation of the Russian interest rate pass-through. As stated above, the objective of this study is to investigate how Russian commercial banks passed changes in their cost of funds due to countercyclical monetary policy, as reflected in changes in the Central Bank policy related rate, to their customers, through the short-run and long-run interest rate passthrough processes, since February 2011.

To achieve the above objective, this study utilizes an Autoregressive Distributed Lag model to empirically investigate the nature of interest rate pass-through in the Russian economy. Estimation results suggest that, based on the Akaike information criterion, the ARDL $(1,5,5)$ model best fits the data. Estimation results of the $\operatorname{ARDL}(1,5,5)$ model reveal that the Russian short-run rates of pass-through ( $\left.\delta_{0}+\rho_{0}=0.662937\right)$ are relatively high as compared to empirical values reported in the literature for the emerging and advanced economies.

The empirical results also indicate that the Russian commercial banks considered their lending rate only one month back in determining their current lending rate, while these same lending institutions took up to five months to respond to the monetary policies completely. The calculated long-run passthrough rate in the Russian banking industry is $\Phi=0.826353$ which is fairly low, indicating that the Russian long-term interest rate passthrough is incomplete or sticky, suggesting the ineffectiveness of this policy.

The result of the testing procedure testing the null hypothesis $H_{0}: \lambda_{1}=\lambda_{2}=\lambda_{3}=0$ is inconclusive, suggesting no long-run relationship between the countercyclical monetary policy and the commercial banks' lending rate in the lending markets. The inconclusive result of the test of the above null hypothesis of no long-run relationship is an indication of the lack of credibility of the Russian Central Bank.

Understanding the behavior of bank interest rates is relevant to conducting monetary policy and also to designing public policies. This investigation studies the nature of interest rate pass-through in the Russian economy. Notwithstanding concerted efforts to reform the economy and to cope with the sharp decline in oil prices, the empirical findings of this study suggest that the Russian Central Bank has not been very effective in formulating and implementing its countercyclical monetary policy. This effort has been further challenged when combined with Western sanctions and Russian counter-sanctions following the RussiaUkraine conflict, which both had a negative impact on the Russian economy and banking sector in recent years. In light of the formidable political and economic challenges faced by the Russian Federation over this sample period, the results are hardly surprising.

\section{REFERENCES}

Alencar, L. S. 2003. O pass-through da taxa básica: Evidência para as taxas de juros bancárias. In: Banco Central do Brasil. Relatório de Economia Bancária e Crédito, pp. 90-100.

Bernanke, B., and Gertler, M. 1992. The Federal Funds Rate and the Channels of Monetary Transmission. American Economic Review, Vol. 82(4), pp. 901-921.

Berstein, S., and Fuentes, R. 2003. From Rate to Bank Lending Rate: The Chilean Banking Industry. LACEA Papers and Proceedings, Mexico, 30p. 
Borio, C., and Fritz, W. 1995. The response of short-term bank lending rates to policy rates: a cross-country perspective. BIS Working Papers, No 27.

Coelho, C., De Mello, J., and Garcia, M. 2010. Identifying the bank lending channel in Brazil through data frequency. Economía, the journal of LACEA, 10, pp. 47-79.

Cottarelli, C., and Kourelis, A. 1994. Financial Structure, bank lending rates, and the transmission mechanism of monetary policy. IMF Staff Papers 41(4), pp. 587-623.

Dhal, S. C., and Ansari, J. 2013. Interest Rate Passthrough and Determinants of Commercial Banks' Loan Pricing Decisions in India: Empirical Evidence from Dynamic Panel Data Model. Banking \& Finance Review. Vol. 5 Issue 1, pp. 91-113.

Enders, W. 2015. Applied Econometric Time Series. $4^{\text {th }}$ edition, John Wiley and Sons, Inc. Hoboken, New Jersey, USA.

Engle, R., and Granger, C. 1987. Cointegration and Error Correction: Representation, Estimation, and Testing. Econometrica, Vol. 55, pp 251-76.

Espinosa-Vega, M., and Rebucci, A. 2003. Retail bank interest rate pass-through: Is Chile atypical?

IMF Working Paper 03/112, 35p.

European Central Bank. 2003. New ECB statistics on MFI interest rates. Monthly Bulletin, December.

Gambacorta, L. 2008. How do banks set interest rates? European Economic Review, Vol 52, pp 792-819.

Gustavo A., Alvarez, H., and Makunin. I. (2016) Russia Industry Resaerch - Banks. RatingAgentur Expert RA GmbH, Walter-KolbStrasse 9-11, (August 26, 2016), Germany, raexpert.eu/files/Industry_reportBanks_26.08.2016.pdf

Hofmann, B., and Mizen, P. 2004. Interest Rate Pass-Through and Monetary Transmission: Evidence from Individual Financial Institutions' Retail Rates, Economica, 71. pp. 99 - 123.

Illes, A., and Lombardi, M. 2013. Interest Rate Pass-through since the Financial Crisis. Bank of International Settlements Quarterly Review, September 2013. www.bis.org/publ/qtrpdf/r_qt1309g.pdf.
IMF (2016-a) Russian Federation Financial System Stability Assessment. IMF Country Report No. 16/231, (July 2016), Washington, D.C., US.

IMF (2016-b) Russian Federation Detailed Assessment of Observation Basel Core Principles for Effective Banking Supervision. IMF Country Report No. 16/303, (September 2016), Washington, D.C., US.

McKinnon, R. I. 1973. Money and Capital in Economic Development. Washington, DC: Brookings Institute.

Mojon, B. 2000. Financial structure and the interest rate channel of ECB monetary policy. European Central Bank Working Paper Series 40, 45p.

Nguyen, C. V. 2017. The Brazilian Interest Rate Pass- Through. Journal of Business and Economic Perspectives, Vol. 44 (1), pp. 2939.

Patrick, H. T. 1966. Financial Development and Economic Growth in Underdeveloped Countries. Economic Development and Cultural Change, Vol. 14, No 2, pp. 174-89.

Pereira, C. M., and Maia-Filho, L.F. 2013. Brazilian Retail Banking and the 2008 Financial Crisis: Were the Government-Controlled Banks that Important? Journal of Banking \& Finance, Vol. 377), pp. 2210-2215.

Perron, P. 1997. Further Evidence on Breaking Trend Functions in Macroeconomic Variables. Journal of Econometrics, 80. pp. 355-385.

Pesaran, M. H. 1997. The Role of Economic Theory in Modelling the Long Run. The Economic Journal, Vol. 107, No. 440 (Jan., 1997), pp. 178-19.

Pesaran, M. H., Shin, Y., and Smith, R. 2001. Bounds Testing Approaches to the Analysis of Level Relationship. Journal of Applied Econometrics, Vol. 16, pp. 289-326.

Sander, H., and Kleimeier, S. 2004. Convergence in euro-zone retail banking? What interest rate pass-through tells us about monetary policy transmission, competition and integration. Journal of International Money and Finance, Vol. 23(3), pp. 461-492.

Schumpeter, J. A. 1912. TheoriederWirtschaftlichenEntwicklung, Liepzig: Duncker and Humblot. Revised English translation by Redvers Opie. The Theory of Economic Development. 
Cambridge, MA: Harvard University Press, 1934.

Sørensen, C. K., and Werner, T. 2006. Bank interest rate pass-through in the Euro area: A cross country comparison. European Central Bank Working Paper Series 580, 63p.

Tonooka, E. K., and Koyama, S. M. 2003. Taxa de juros e concentração bancária no Brasil. Trabalho para Discussão Banco Central do Brasil 62, 35p.

Weth, M. 2002. The Pass-Through from Market Interest Rates to Bank Lending Rates in Germany. Discussion paper Series 1 / Volkswirtschaftliches Forschungszentrum der Deutschen Bundesbank, No. 2002, 11

Wickens, M., and Breusch, T. 1988. Dynamic specification, the long run and the estimation of transformed regression models. Economic Journal, 98, pp. 189-205.

\section{ABOUT THE AUTHORS}

Chu Nguyen, e-mail address: nguyenchu@uhd.edu

Dr. Chu V. Nguyen is an Associate Professor of Economics and Finance and Chair of the FAEIS Department at the Marilyn Davies College of Business, University of HoustonDowntown. He earned an MA in Economics, an $\mathrm{MS}$ in Mathematics and $\mathrm{a} \mathrm{PhD}$ in Economics from the University of Cincinnati. $\mathrm{He}$ is also the Chairman of the Board of Directors of Tropical Star Enterprise, Inc. He served as an economist and then the Head of the Economic Analysis and Forecasting Department at the $5^{\text {th }}$ District of Federal Home Loan Bank System. He published over 85 publications in reputable US and international peer-reviewed journals.

Dr. Phan Dinh Khoi is an Assistant Professor of Finance and Chair of the Department of Finance and Banking at the College of Economics, Can Tho University, Vietnam. He earned a $\mathrm{PhD}$ in Finance from Lincoln University in New Zealand. He published a few papers in international peer-reviewed journals including Journal of Asian Economics and the Journal of Asia-Pacific Economy. His research interest focuses on development finance, development economics, corporate finance, and banking.

Dr. Marvin J. Williams is a Professor of Accounting and Taxation at the Marilyn Davies College of Business, University of Houston-Downtown. He earned a BBA in Accounting, an MBA in Finance and a JD in Law from the University of Houston. He teaches courses in Federal Taxation (undergraduate and graduate) and Accounting. $\mathrm{He}$ is a Certified Public Accountant (CPA), Certified Management Accountant (CMA), Certified in Financial Management (CFM) and Chartered Global Management Accountant (CGMA) as well as an Attorney At Law. 